\title{
Whitening and anti-wrinkle effect of Spirodela polyrhiza extracts
}

\author{
Dong Hee Kim ${ }^{1}$ (D) Tae Soon $\operatorname{Park}^{1}$ (D) $\cdot$ Se Gie Kim²

\section{부평초 추출물의 미백 및 항주름 효과}

\author{
김동희 ${ }^{1} \cdot$ 박태순 $^{1} \cdot$ 김세기 $^{2}$
}

Received: 17 October 2019 / Accepted: 29 October 2019 / Published Online: 31 December 2019

(C) The Korean Society for Applied Biological Chemistry 2019

\begin{abstract}
The antioxidant, whitening, and anti-wrinkle activity of Spirodela polyrhiza extracts and fractions were evaluated to determine its efficacy as a functional cosmetic material. 1,1diphenyl-2-picrylhydrazyl and 2,2'-azinobis-3-ethylbenzothiazoline6-sulfonic acid radical scavenging activities were 44.2 and $74.3 \%$, respectively, at $100 \mu \mathrm{g} / \mathrm{mL}$ of SE-E (the ethyl acetate fraction of $70 \%$ ethanol extract). To measure anti-wrinkle effects, procollagen biosynthesis and matrix metalloproteinase-1 (MMP-1) inhibition activity were determined. At $25 \mu \mathrm{g} / \mathrm{mL}$ of SE ( $70 \%$ ethanol extract), the biosynthesis activity was $48.5 \%$, and SE-E showed the best activity $(57.8 \%)$ at the same concentration. MMP-1 inhibition activity of SE and SE-E was 13.4 and $28.5 \%$, respectively, at 25 $\mathrm{ig} / \mathrm{mL}$. Finally, the inhibition of cellular melanin synthesis and cellular tyrosinase were measured to determine the whitening effect; at $25 \mu \mathrm{g} / \mathrm{mL}$, the inhibition activities of SE were 9.6 and $13.8 \%$, respectively, and those for SE-E were 15.4 and $22.0 \%$, respectively. Our results confirmed the possibility of SE and SE$\mathrm{E}$ as effective functional materials. Further research investigating the antimicrobial, anti-inflammatory, and anticancer activities of $S$.
\end{abstract}

Dong Hee Kim and Tae Soon Park are equally contributed to this work.

Se Gie Kim $(\triangle)$

E-mail: sgkim7@cu.ac.kr

${ }^{1}$ National Institute For Korean Medicine Development, Gyeongsan 38540, Republic of Korea

${ }^{2}$ Department of Pharmaceutical Engineering, Daegu Catholic University, Gyeongsan 38430, Republic of Korea

This is an Open Access article distributed under the terms of the Creative Commons Attribution Non-Commercial License (http://creativecommons. org/licenses/by-nc/3.0/) which permits unrestricted non-commercial use, distribution, and reproduction in any medium, provided the original work is properly cited. polyrhiza is necessary to confirm its potential use in the food, cosmetics, and drug industries.

Keywords Anti-oxidant · Anti-wrinkle - Functional cosmetics · Spirodela polyrhiza $\cdot$ Whitening

\section{서 론}

국내 기능성 식품 및 화장품 산업은 21세기에 들어서 크게 발 전하고 있으며 이중 화장품 산업의 개발 추세는 친환경, 저자 극 화장품에 있다. 일부 화장품은 값싼 원료를 대량으로 얻기 위해 피부자극을 유발하는 유기합성 성분이 사용되고 있으며, 피부 트러블이 자주 논란이 되고 있다[1,2]. 따라서 국내외 유 수의 화장품 업체들은 피부자극이 강한 성분을 저자극, 천연소 재로 대체하는 노력을 활발히 경주하고 있다. 또한 미백, 주름 개선, 자외선 차단기능을 갖는 기능성 화장품의 매출이 크게 늘 고 있어, 식물계 소재를 이용한 기능성 화장품 소재개발이 매 우 활발하다[3,4]. 활성산소(Reactive Oxygen Species, ROS)는 진피 또는 표피 조직을 공격하고, 엘라스틴(elastin)의 분해 효 소인 elastase를 활성화시킨다[5]. 활성화 된 elastase는 엘라스틴 단백질의 3 차 구조를 변형시켜 진피의 유연성을 감소시키고 피 부주름을 생성한다[6]. 피부노화는 그 요인에 따라 내인적 노화 (intrinsic aging)와 외인적 노화(extrinsic aging)로 구분할 수 있 다. 외인적 노화는 외부 스트레스에 의해 노화 현상이 나타나 는 것으로 자외선에 의한 광노화가 주된 원인이다. 자외선을 받 게 되면 교원질(collagen) 및 탄력섬유(elastin fiber) 등의 기질 단백질이 손상되어 피부 내 교원질의 양이 부족해지고 탄력섬 유가 변성되어 주름을 유발하며 기미, 주근깨 및 검버섯이 증 가하는 현상을 보인다[7,8]. 또한 자외선에 노출되면, $\alpha$ melanocyte stimulating hormone ( $\alpha-\mathrm{MSH})$, adrenocorticotropic 
hormone 등의 신호전달물질을 멜라닌세포로 분비하게 된다[9]. 멜라닌은 melanosome 내부에서 생성되고 아미노산인 L-tyrosine 이 효소인 tyrosinase에 의해 dopaquinone으로 전환된다. 그러나 과도한 멜라닌 생성은 흑색증, 염증 후 색소 침착, 주근깨 또는 종자와 같은 상태에서 상당한 문제를 일으킬 수 있다[10]. 기능 성화장품 개발 관련 연구에서는 피부 미백과 주름 개선 효능이 있는 다양한 소재 연구가 활발하게 진행되고 있으며 특히 웰빙 트렌드 확산으로 안전하고 우수한 효능을 함유한 천연 소재 개 발에 초점을 맞추고 있다[11,12].

부평초(Spirodelae Herba)는 개구리밥과(Lemnaceae)에 속한 다년생 수생식물인 개구리밥(Spirodela polyrhiza (L.) Schleid)과 청평(Lemna minor L.), 좀개구리밥(Lemna paucicostata Hegelm) 의 전초를 건조한 것으로, 6 월9월 사이에 채취하여 씻어 불순 물을 제거한 다음 건조하여 치료에 사용되고 있는 한약재이다. 부평초의 성분에 관한 연구로 개구리밥(S. polyrhiza)에서 campesterol, $\beta$-sitosterol, stigmasterol 등의 sterol [13]과 apigenin7- $O$ - $\beta$-D-glucoside, cynaroside, hypolaetin- $8-O-\beta$-D-glucoside, vitexin, orientin 등의 flavonoid, anthocyanin 및 tannin 등이 보고되어 있다[14,15]. 예로부터 한방과 민간에서는 부평초를 말 려 부종, 수종, 갈증, 강장, 발한, 해독, 충독, 수독, 양모, 당뇨 병, 창종, 화상 등 피부와 관련된 질환의 약재로 사용하였으며 $[16,17]$ 이를 근거로 아토피관련 효능, 피부재생관련 효능, 항염 증관련 효능, 피부 진정관련 효능, 피부미백관련 효능을 객관적 으로 검증하여 바이오 소재화할 수 있을 것으로 사료된다. 또 한 부평의 효능에 관한 연구로서 비만의 원인인 수습정체, 담 음, 양허 등에 부평이 효과가 있는 것으로 생각되어 지방세포 합성에 미치는 영향을 관찰한 결과 유의성 있는 결과가 있는 것으로 보고된바 있으며[18], 면역과 아토피관련 효능, 항암 활 성에 대한 연구 $[19,20]$ 와 부평초의 화학성분 및 항산화효과에 관한 연구 등이 일부 보고된 바 있어 건강 바이오 소재나 다이 어트 소재로서도 활용 가능성이 있을 것으로 생각된다. 본 연 구에서는 수생식물로부터 항산화, 항주름 및 미백 활성을 나타 내는 천연소재를 탐색하고자 다양한 수생식물을 대상으로 효능 을 조사, 평가하였으며, 그 중에서 우수한 생리활성을 나타낸 부평초 $(S$. polyrhiza $) 70 \% \mathrm{EtOH}$ 추출물 및 각 분획물의 강한 라디칼 소거활성, 항주름 및 미백 활성을 검증하고 그 결과를 보고하고자 한다.

\section{재료 및 방법}

\section{실험재료 및 추출물의 제조}

부평초(S. polyrhiza)는 경산시 소재 약업사로부터 2016년 9월에 구입하였으며 원산지는 중국이다. 증거 표본은 한국한의약진흥 원 표본실에 보관중이다. 부평초 물 추출물 $(\mathrm{SW})$ 은 시료 $200 \mathrm{~g}$ 을 환류 냉각하여 3 시간 2회 반복 열수 추출하였다. 이후 열수 추출물을 여과하고 농축, 동결 건조하여 건조 중량 $23.5 \mathrm{~g}$ 을 얻 었으며 수율은 $11.8 \%$ 이였다. 부평초 $70 \%$ 에탄올추출물 $(\mathrm{SE})$ 은 부평초 $4 \mathrm{~kg}$ 을 $70 \%$ 에탄올 $30 \mathrm{~L}$ 를 사용하여 상온에서 2 일간 침지시켜 2회 반복 추출하였다. 추출액을 여과하여 $40{ }^{\circ} \mathrm{C}$ 이하 에서 감압 하에 완전히 농축하고 동결 건조하여 건조 중량 $480.29 \mathrm{~g}$ 을 얻었으며 수율은 $12.0 \%$ 이었다. 이 중 $457.2 \mathrm{~g}$ 을 증
류수에 현탁 시킨 후 용매 극성에 따라 $n$-hexane, EtOAc 및 $n$ - $\mathrm{BuOH}$ 을 이용하여 순차적으로 분획하여 $n$-hexane 분획물(SE$\mathrm{H}) 94.05 \mathrm{~g}, \mathrm{EtOAc}$ 분획물(SE-E) $68.80 \mathrm{~g}, n-\mathrm{BuOH}$ 분획물 (SE-B) $50.26 \mathrm{~g}$ 을 얻었다. 나머지는 $\mathrm{H}_{2} \mathrm{O}$ 분획물 $(\mathrm{SE}-\mathrm{W})$ 로 하였 으며 $212.09 \mathrm{~g}$ 이 얻어져서 각각의 회수율은 순서대로 20.6, $15.0,11.0,46.4 \%$ 이었다.

\section{DPPH 라디칼 소거 활성}

부평초 추출물 및 분획물의 1,1-diphenyl-2-picrylhydrazyl (DPPH) 라디칼 소거 활성은 Blois 방법[21]에 따라 측정하였다. 각 시 료용액에 $100 \mu \mathrm{L}$ 에 $0.02 \mathrm{mM}$ 의 희석한 $\mathrm{DPPH}$ 용액 $50 \mu \mathrm{L}$ 을 넣 고 교반한 후 10 분간 방치한 다음 microplate reader (Sunrise $^{\mathrm{TM}}$, Tecan Group Ltd., Männedorf, Switzerland)를 이용하여 517 $\mathrm{nm}$ 에서 흡광도를 측정하였다. 이때 대조물질로는 Butylated Hydroxy Anisole (BHA)를 사용했으며 DPPH 라디칼 소거 활 성은 시료용액의 첨가군과 무첨가군의 흡광도비로부터 산출하 였다.

\section{$\mathrm{ABTS}^{+}$라디칼 소거 활성 측정}

부평초 추출물 및 분획물의 2,2'-azinobis-3-ethylbenzothiazoline6-sulfonic acid (ABTS) radical 소거 활성을 $\mathrm{Re}$ 등의 방법[22] 을 변형하여 다음과 같이 측정하였다. $7 \mathrm{mM} \mathrm{ABTS} \mathrm{(in} \mathrm{water)}$ 와 $2.4 \mathrm{mM} \mathrm{K} \mathrm{K}_{2} \mathrm{O}_{2}$ 동량을 혼합 후 실온, 암소에서 12시간 방 치하여 라디칼의 생성을 유도한 후 $\mathrm{ABTS}^{+}$라디칼 용액을 희 석하여 $734 \mathrm{~nm}$ 에서 흡광도 값이 0.6-0.7 정도가 되도록 희석하 여 사용하였다. 희석한 $\mathrm{ABTS}^{+}$라디칼 용액 $100 \mu \mathrm{L}$ 와 생약 추 출액 $50 \mu \mathrm{L}$ 을 혼합하여 실온에서 7분간 반응시킨 후 $734 \mathrm{~nm}$ 에 서 흡광도를 측정하였다. 이때 대조물질로는 $\mathrm{BHA}$ 를 사용하였 으며 결과는 시료를 처리하지 않은 군에 대한 흡광도비로부터 산출하였다.

\section{세포 배양 및 세포 생존율 측정}

본 실험에 이용한 각 세포의 배양은 $10 \%$ fetal bovine serum 과 $1 \%$ penicillin $(100 \mathrm{U} / \mathrm{mL})$ 을 첨가한 Dulbeco's modified eagle's medium (DMEM) (Invitrogen Carlsbad, CA, USA) 배 지를 사용하였으며, $37^{\circ} \mathrm{C}, 5 \% \mathrm{CO}_{2}$ incubator에 적응시켜 계대 배양하였다. 세포 생존율 측정은 Park 등의 방법[23]에 따라 측 정하였다. 각 세포주[melanoma (B16F10) (ATCC, Rockville, MD, USA), fibroblast (CCD-986sk) (ATCC, Rockville, MD, USA)]를 96 well plate에 $0.6-8 \times 10^{3}$ cells/well이 되게 $180 \mu \mathrm{L}$ 분주하고, 시료를 농도 별로 조제하여 $20 \mu \mathrm{L}$ 첨가한 후 $37^{\circ} \mathrm{C}$, $5 \% \mathrm{CO}_{2}$ incubator에서 24시간 배양하였다. 대조군은 시료와 동 량의 증류수를 첨가하여 동일한 조건으로 배양하였다. 여기에 5 $\mathrm{mg} / \mathrm{mL}$ 농도로 제조한 $\mathrm{MTT}$ 용액 $20 \mu \mathrm{L}$ 를 첨가하여 4시간 배 양한 후 배양액을 제거하고 각 well당 DMSO $200 \mu \mathrm{L}$ 를 가하 여 실온에서 15 분간 반응 시킨 뒤 microplate reader Sunrise $^{\mathrm{TM}}$, Tecan Group Ltd., Männedorf, Switzerland)로 $540 \mathrm{~nm}$ 에서 흡 광도를 측정하였다.

\section{Procollagen type 생합성 및 MMP-1 저해 활성 측정}

CCD-986sk 세포를 $5 \times 10^{4}$ cells/well 농도로 12 well plate에 접종한 후, $\mathrm{UVB}\left(20 \mathrm{~mJ} / \mathrm{cm}^{2}\right)$ 를 조사한 후 시료를 농도별로 처 
리 하여 $\mathrm{CO}_{2}$ 배양기에서 48시간 배양하였다. 이렇게 실험한 세 포의 상등액을 모아서 실험에 사용하였다. 세포 배양액 내 콜 라겐 생합성 정도는 procollagen type-C peptide (PIP) EIA kit (Takara, Shiga, Japan)를 사용하여 propeptide의 양을 측정하였 으며, MMP-1 저해 활성 측정은 matrix metalloproteinase-1 ELISA kit (Abcam, Cambridge, MA, USA)을 이용하여 측정 하였다.

\section{Melanin 생합성 및 cellular tyrosinase 저해 활성 측정}

피부 melanoma 세포로부터의 melanin 생합성 저해 측정은 Hosoi 등의 방법[24]에 따라 측정하였다. DMEM 배지로 배양 된 melanoma 세포를 $100 \mathrm{~mm}$ culture dish에 $2 \times 10^{6} \mathrm{cell} / \mathrm{dish}$ 가 되게 분주하고, 24 시간 배양 후 $\alpha-\mathrm{MSH}$ 를 처리한 후 시료를 농 도 별로 조제하여 $2 \mathrm{~mL}$ 첨가하고, 48시간 후에 인산완충액 $(\mathrm{pH}$ 7.4)으로 세척하였다. 그 다음 $0.25 \mathrm{M}$ trypsin-EDTA 용액으로 세포를 탈착한 후 수확한 세포를 $1 \times 10^{6}$ cell 당 $1 \mathrm{~mL}$ 의 $5 \%$ $\mathrm{TCA}$ 로 처리하고, $2,500 \mathrm{rpm}$ 으로 2 회 원심분리한 후 분리된 melanin을 인산완충액으로 세척한 뒤 ether:ethanol (1:3) $1 \mathrm{~mL}$ 를 가하여 2회 원심분리 한 후 ether $1 \mathrm{~mL}$ 로 세척 건조시킨다. 건조된 melanin에 $1 \mathrm{~N} \mathrm{NaOH}$ 를 $1 \mathrm{~mL}$ 가하여 $80^{\circ} \mathrm{C}$ 에서 1 시간 반응시킨 후 분광 광도계 $405 \mathrm{~nm}$ 에서 흡광도를 측정하였다. Cellular tyrosinase 저해 활성 측정은 $\mathrm{B} 16 \mathrm{~F} 10$ melanoma 세포 를 6 well에 $5 \times 10^{4}$ cello이 되도록 접종하여 배양하고, 24 시간 뒤 각 well에 시료를 48시간 동안 처리하였다. 처리 후 PBS로 2 회 세척한 후 각 well의 세포에 lysis buffer ( $1 \%$ triton X100, 0.1 M Sodium phosphate buffer, $50 \mathrm{mM}$ PMSF, pH 6.8) 를 가하였다. 얼음 위에서 세포를 파괴시키고 원심 분리한 후 상층액만 따로 모아 효소용액으로 사용하였다. L-DOPA를 2 $\mathrm{mg} / \mathrm{mL}$ 농도로 $0.1 \mathrm{M}$ sodium phosphate buffer ( $\mathrm{pH}$ 6.8)에 녹 여 기질을 준비하고 기질 $160 \mu \mathrm{L}$ 에 효소용액 $40 \mu \mathrm{L}$ 를 가하고 $37^{\circ} \mathrm{C}$ 에서 1 시간 가온하고 생성된 $\mathrm{DOPA}$ chrome의 양을 490 $\mathrm{nm}$ 에서 측정하였다. Melanin 생합성 저해와 Cellular tyrosinase 활성은 시료 용액의 첨가군과 무첨가군의 흡광도비로부터 산출 하였다.

\section{Western blot을 통한 단백질의 발현 측정}

MMP-1, MMP-9, Tyrosinase, TRP-1, TRP-2, microphthalmia transcription factor 저해활성을 보기 위하여 각각의 세포를 60 $\mathrm{mm}$ tissue culture dish에 cell seeding 후 24시간 동안 배양하 여 세포를 안정화 시켰다. 배지를 제거한 후 UVB $\left(20 \mathrm{~mJ} / \mathrm{cm}^{2}\right)$ 로 조사하고 추출물을 농도 별로 처리한 배지로 24-48시간 배 양한 후 다시 배지를 제거하고 PBS로 2번 세척해주었다. RIPA buffer $10 \mathrm{~mL}$ 에 complete mini 1 tab를 가함 $100 \mu \mathrm{L}$ 로 용해해 서 $4{ }^{\circ} \mathrm{C} \quad 12,000 \mathrm{rpm}$ 에서 20 분간 원심 분리 하였다. 원심 분리 하여 얻은 상층액은 bradford assay로 정량하여 $20 \mu \mathrm{L}$ 의 단백질 을 $10 \%$ 의 SDS-PAGE를 이용하여 전기 영동하여 분리하였다. 분리된 단백질은 semi dry transfer cell 기기(Hofer, Holliston, MA, USA)를 이용하여 PVDF membrane (EMD millipore, billerica, $\mathrm{MA}, \mathrm{USA})$ 에 옮긴 다음 실온에서 1시간 blocking buffer $(5 \%$ skim milk in TBST)에서 incubation 시켰다. 1차 항체를 희석하여 $4^{\circ} \mathrm{C}$ 에서 over night한 다음, 다시 10 분 간격으로 TBST로 3회 세척하고 mouse anti-rabbit IgG HRP (Santa Cruz
Biotechnology Inc, Dallas, TX, USA), bovine anti-goat IgG HRP (Santa Cruz Biotechnology Inc)의 각각의 2차 항체를 $1: 1,000$ 로 희석하여 실온에서 2시간 동안 배양하였다. 3회 세척 한 뒤 LAS 4,000(GE Healthcare, Uppsala, Sweden) 기기를 이용하여 밴드 확인 및 정량하였다.

\section{통계처리}

모든 실험은 3회 이상 반복하여 실시하였으며 평균치와 표준편 차로 나타내었으며, 유의성 검증은 SPSS statistics 20 (IBM, Armonk, NY, USA) software package program을 이용하여 Duncan's multiple range test와 t-test를 실시하였으며 통계적 유 의수준 $p<0.05,0.01$ 에서 검증하였다.

\section{결과 및 고찰}

\section{DPPH 및 $\mathrm{ABTS}^{+}$라디칼 소거 활성 측정 결과}

부평초 열수추출물 $(\mathrm{SW})$, 에탄올추출물(SE)과 에탄올추출물의 용 매별 분획물에 대한 $\mathrm{DPPH}$ 라디칼 소거활성 측정 결과를 Fig. 1 에 나타내었다. SE는 $100 \mu \mathrm{g} / \mathrm{mL}$ 농도에서 $36.1 \%$ 의 소거활성 을 나타내었고, $\mathrm{SW}$ 는 $100 \mu \mathrm{g} / \mathrm{mL}$ 농도에서 $24.7 \%$ 의 소거능을 나타내어 $\mathrm{SE}$ 가 SW보다 $\mathrm{DPPH}$ 라디칼 소거활성이 우수하였다. 부평초 $70 \%$ 에탄올 추출물의 용매별 분획물의 경우 $100 \mu \mathrm{g} / \mathrm{mL}$ 농도의 SE-E와 SE-B에서 각각 $44.2,42.6 \%$ 의 $\mathrm{DPPH}$ 라디칼 소거 활성을 나타내었다. 이러한 결과는 머루 과피[25]와 선학 초[26] 용매별 분획물에서 $\mathrm{EtOAC}, \mathrm{BuOH}$ 분획물의 높은 $\mathrm{DPPH}$ 라디칼 소거활성 결과와 유사한 경향을 나타냄을 확인할 수 있었다.

부평초 추출물들의 $\mathrm{ABTS}^{+}$radical 소거능 측정 결과는 Fig. 2 와 같이 확인되었다. $\mathrm{SE}$ 의 경우 $100 \mu \mathrm{g} / \mathrm{mL}$ 의 농도에서 $91.0 \%$ 로 열수 추출물보다 $\mathrm{ABTS}^{+}$radical 소거 활성이 우수하였다. $\mathrm{SE}$ 의 용매별 분획물 중에서는 SE-E가 $100 \mu \mathrm{g} / \mathrm{mL}$ 의 농도에서 $74.3 \%$ 소거활성을 나타내어 분획물 중 가장 우수한 $\mathrm{ABTS}^{+}$ radical 소거 활성을 나타내었다. 이는 눈개승마 용매 분획물 중 $\mathrm{EtOAC}$ 분획물에서 $\mathrm{ABTS}^{+}$radical 소거능이 $500 \mu \mathrm{g} / \mathrm{mL}$ 농도에 서 $99.2 \%$ 로 높게 나온 것과 비교될 수 있는 결과이다[27].

\section{CCD-986sk fibroblast 세포에 관한 MTT 측정 결과}

CCD-986sk 세포에 대한 부평초의 세포 생존율을 측정한 결과, 대조군에 비해 부평초 에탄올, 열수 추출물과 용매별 분획물은 $25 \mu \mathrm{g} / \mathrm{mL}$ 의 농도 이하에서 $80 \%$ 이상의 세포생존율을 나타내었 으며, B16F10세포에서도 대조군에 비해 $25 \mu \mathrm{g} / \mathrm{mL}$ 의 농도 이하 에서 모두 $80 \%$ 이상의 생존율을 나타내는 것을 확인하였다(Fig. 2 ). 따라서 $\mathrm{SW}, \mathrm{SE}$ 및 $70 \%$ 에탄올 용매 별 분획물은 세포생 존율 결과를 바탕으로 $25 \mu \mathrm{g} / \mathrm{mL}$ 의 농도에서 procollagen 생합 성, $\mathrm{MMP}-1$ 저해 활성, melanin 생합성 저해활성, tyrosinase 저해 활성 등을 검증 하였다.

\section{Procollagen type 생합성 kit 측정 결과 및 MMP-1 저해 활성 kit 측정 결과}

Procollagen은 아미노 말단과 카르복시 말단에 propeptide라는 peptide 염기서열을 포함한다. Propeptide는 소포체내에서 

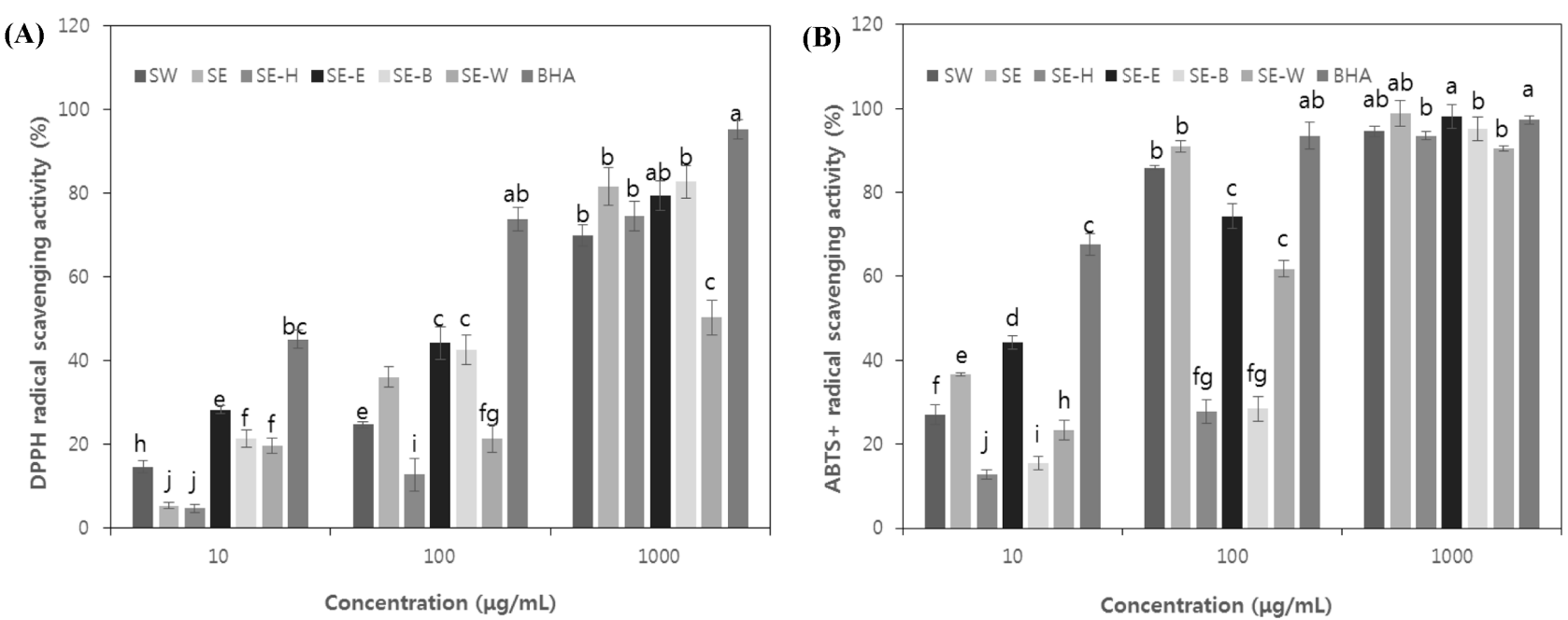

Fig. $1 \mathrm{DPPH}$ and $\mathrm{ABTS}^{+}$radical scavenging activity of extracts and fractions from $S$. polyrhiza. (A), DPPH radical scavenging activity of extracts and fractions from $S$. polyrhiza.; (B), ABTS ${ }^{+}$radical scavenging activity of extracts and fractions from $S$. polyrhiza., $\square$ SW, S. polyrhiza extracted with Water; SE, S. polyrhiza extracted with 70\% EtOH; $\square$ SE-H, Hexane fraction of SE; $\square$ SE-E, Ethyl acetate fraction of SE; $\square$ SE-B, Butanol fraction of SE; SE-W, Water fraction of SE. The results were expressed as the average of triplicate. Means not sharing a common letter (a-i) are significantly different $(p<0.05)$ by Duncan's multiple range test
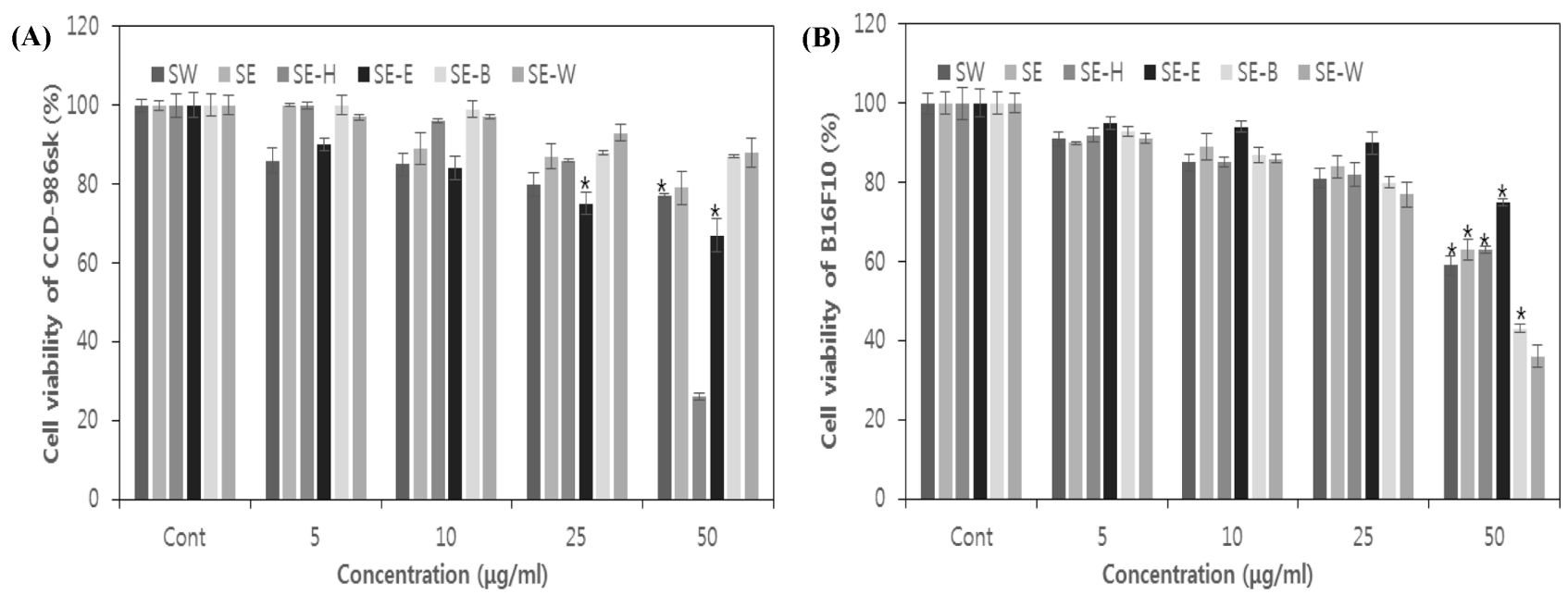

Fig. 2 Cell viability of CCD-986sk and B16F10 cells after treatment with extracts and fractions from S. polyrhiza. (A), Cell viability of CCD-986sk.; (B), Cell viability of CCD-986sk, SW, S. polyrhiza extracted with Water; SE, S. polyrhiza extracted with 70\% EtOH; $\square$ SE-H, Hexane fraction of SE; $\square$ SE-E, Ethyl acetate fraction of SE; SE-B, Butanol fraction of SE; SE-W, Water fraction of SE. The results were expressed as the average of triplicate. Significant differences were compared with control at $* p<0.05$ compared with no treatment

procollagen 분자의 folding을 도와줌과 동시에 collagen 중합반 응이 일어날 때 collagen 분자로부터 절단, 분리된다고 알려져 있다. 따라서 propeptide의 양을 측정함으로써, 세포 내에서의 collagen 생합성 정도를 파악할 수 있다[28]. 섬유아세포에 대한 procollagen type C-peptide enzyme immunoassay에 의한 collagen 생합성량을 측정한 결과 Fig. 6과 같이 나타내었다. SW, SE의 경우 $25 \mu \mathrm{g} / \mathrm{mL}$ 의 농도에서 각각 $35.4,48.5 \%$ 의 procollagen 생 합성량을 나타내었다. 부평초의 용매별 분획물의 경우 $\mathrm{SE}-\mathrm{E}$ $(57.8 \%)>$ SE-W $\quad(43.8 \%)>$ SE-B $\quad(41.5 \%)>$ SE-H $\quad(32.3 \%)$ 순 으로 procollagen 생합성 활성을 나타내었다. Koo 등[29]의 보 고에 의하면, 사상자 용매별 분획물의 경우에는 $\mathrm{BuOH}>\mathrm{EtOAC}$
$>$ water $>$ hexane 분획 순으로 콜라겐 생합성의 증가가 확인되 었다. 본 실험 결과에서는 SE-W가 SE-B보다 활성이 조금 높 은 것으로 나타났지만 그 차이가 크지 않으므로 전체적으로는 EtOAC와 $\mathrm{BuOH}$ 분획물의 procollagen 생합성 활성이 우수한 경향을 유지하였다.

체내에서 생성되는 수종의 MMPs 가운데 MMP-1은 콜라겐 에 특이적으로 작용하는 protease로서 MMP-1의 활성을 억제하 여 콜라겐의 분해를 감소시키면, 피부조직의 탄력을 유지하고 주름생성을 예방할 수 있는 것으로 알려져 있다[30]. 부평초의 MMP-1 저해 활성 측정 결과는 Fig. 3에서 나타내었다. 그 결 과, $\mathrm{SE}$ 의 경우 $25 \mu \mathrm{g} / \mathrm{mL}$ 의 농도에서 $13.4 \%$ 를 나타내어 $2.3 \%$ 

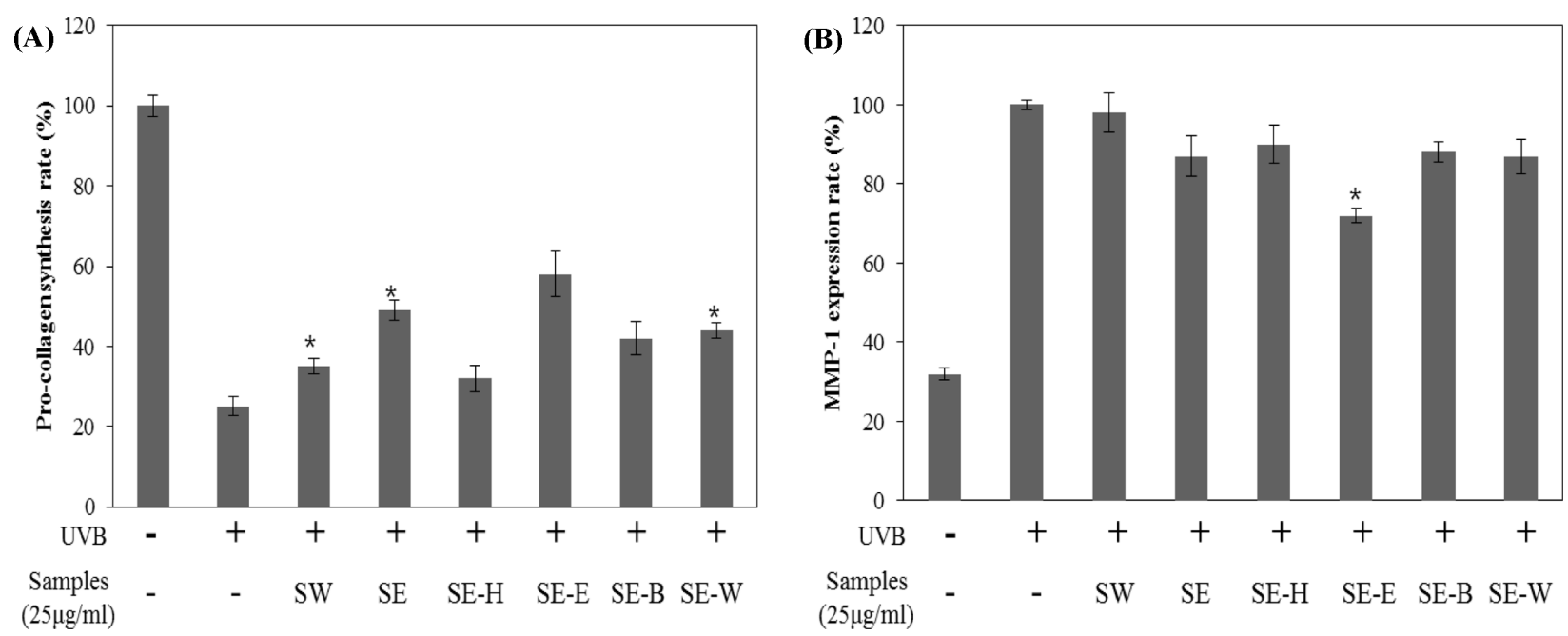

Fig. 3 Procollagen synthesis and MMP-1 inhibition activity on human dermal fibroblast treated with extracts and fractions from $S$. polyrhiza. UVB (20 $\mathrm{mJ} / \mathrm{cm}^{2}$ )-exposed cells were cultured for $48 \mathrm{~h}$ in the presence of $S$. polyrhiza. (A), Procollagen synthesis activity on human dermal fibroblast.; (B), MMP-1 inhibition activity on human dermal fibroblast nor, normal control group (non irradiated-vehicle); con, negative control group (UVB irradiated vehicle); SW, S. polyrhiza extracted with Water; SE, S. polyrhiza extracted with 70\% EtOH; SE-H, Hexane fraction of SE; SE-E, Ethyl acetate fraction of SE; SE-B, Butanol fraction of SE; SE-W, Water fraction of SE. The results were expressed as the average of triplicate. Significant differences were compared with control at $* p<0.05$ compared with no treatment

의 저해 활성을 나타낸 SW보다 효과가 우수하였다. SE-E의 경 우 대조군에 비해 $28.5 \%$ 의 저해율을 나타내어 분획물 중에서 MMP-1 저해활성이 가장 우수하였다. 이는 $\mathrm{Koo}$ 등[29]이 연구 한 사상자 $\mathrm{EtOAC}$ 분획물의 대조군 대비 3-12\% 수준의 MMP1 저해활성을 나타낸 결과와 비교해 보았을 때 SE-E의 MMP1 저해활성이 뛰어남을 확인할 수 있었다. 결론적으로 Procollagen type 생합성 측정 결과와 MMP-1 저해활성 측정 결과 모두에 서 $\mathrm{SE}$ 와 이의 분획물들은 control 대비 positive 활성을 나타내 어 피부 주름 개선을 위한 소재로서 가능성을 보였으며 특히 $\mathrm{SE}-\mathrm{E}$ 는 가장 우수한 활성이 확인되었다.

\section{MMP-1, MMP-9의 단백질 발현 저해 활성 측정 결과}

노화와 관련된 인자인 MAPK에 가장 많은 영향을 받은 인자 는 c-fos이며 이는 p38의 영항을 받는다. 이러한 요인들이 활성 화되면 MMPs의 발현을 강력히 조절한다[31]. 본 연구에서는 MMP family 중 MMP-1, MMP-9의 단백질 발현을 측정하였다. SE-E 처리군에서 MMP-1와 MMP-9의 protein 발현이 5, 10, $25 \mu \mathrm{g} / \mathrm{mL}$ 의 농도에 의존적으로 모두 저해 되었다(Fig. 4). 특히 MMP-1의 protein 측정 시 $25 \mu \mathrm{g} / \mathrm{mL}$ 의 농도에서 $58.2 \%$ 의 발현 저해 활성을 나타내었다. 이와 같은 결과는 산거울 추출물의 EtOAC 분획물 결과[32]와 비교했을 때 유사한 경향이 확인되 며, 산거울의 EtOAC 분획물이 $100 \mu \mathrm{g} / \mathrm{mL}$ 의 농도에서 $60 \%$ 의 MMP-1 발현 저해 활성을 나타내었으므로 SE-E는 우수한 저해 활성이 있음을 확인할 수 있었다.

\section{Melanin 생합성 저해 활성 측정 결과 및 Cellular tyrosinase 활성 측정 결과}

피부 흑화는 피부에 존재하는 melanocyte가 UV 노출 등의 외 부적 환경에 대응하여 melanin의 생성을 증가시키기 때문이다. 원료 및 물질의 미백효능을 확인하기 위해 melanin 생성효소인 tyrosinase의 효소활성 억제 탐색이 주요하게 이용되어 왔으나 최근 효소활성억제와 더불어 미백원료가 melanocyte에서 tyrosinase와 관련 효소 발현을 증가시키는 환경에서 신호전달 체계를 교란시키는 기전 연구에 대한 보고가 매우 많아졌다 [33,34]. SW, SE 등의 melanin 생합성 저해활성을 측정한 결과 는 Fig. 5에 나타내었다. SE의 경우 $25 \mu \mathrm{g} / \mathrm{mL}$ 의 농도에서 $9.6 \%$ 의 저해활성을 나타내었고, SE-E의 경우 $25 \mu \mathrm{g} / \mathrm{mL}$ 의 농도 에서 $15.4 \%$ 로 분획물 중 melanin 생합성 저해활성이 가장 우 수하였다. Cho의 연구 보고[35]에 따르면 파래 추출물의 EtOAc 분획물의 실험 농도 $100 \mu \mathrm{g} / \mathrm{mL}$ 에서 $15 \%$ 의 melanin 생합성 감 소율을 나타내어 분획물중 EtOAc 분획물이 가장 우수하였다. 이는 부평초 분획물 중 $\mathrm{EtOAc}$ 분획물의 활성이 가장 우수한 것과 유사한 경향의 실험결과이다.

Tyrosinase는 피부가 자외선에 노출되면 tyrosine에서 melanin 생성에 가장 중요하게 작용하는 효소이다. Tyrosinase 활성을 저 해함으로써 melanin 생성을 억제 할 수 있으며 이로 인해 기미, 주근깨, 노인성 홍반 등의 유발을 막을 수 있는 것으로 알려져 있다[36]. 세포내 tyrosinase 활성을 측정하기 위하여 $\mathrm{B} 16 \mathrm{~F} 10$ melanoma 세포에 부평초 에탄올, 열수 추출물을 처리하여 tyrosinase 활성을 측정한 결과는 Fig. 13에 나타내었다. SW와 $\mathrm{SE}$ 의 경우 $25 \mu \mathrm{g} / \mathrm{mL}$ 의 농도에서 각각 2.7 와 $13.8 \%$ 의 세포내 tyrosinase 저해활성을 나타내었다. 분획물의 경우 SW-E가 $22.0 \%$ 로 저해활성이 가장 우수하였다.

\section{MITF, TRP-1, TRP-2, Tyrosinase의 단백질 발현 저해 활성 측정 결과}

B16F10 melanoma cell은 melanocyte의 세포막에 존재하는 melanocortin 1 receptor (Mc1R)을 통해 멜라닌 합성의 발현을 유도하는 것으로 알려져 있다[37]. 이 과정에서 microphthalmia transcription factor (MITF)는 핵으로 이동하여 DNA의 tyrosinase, 
(A)

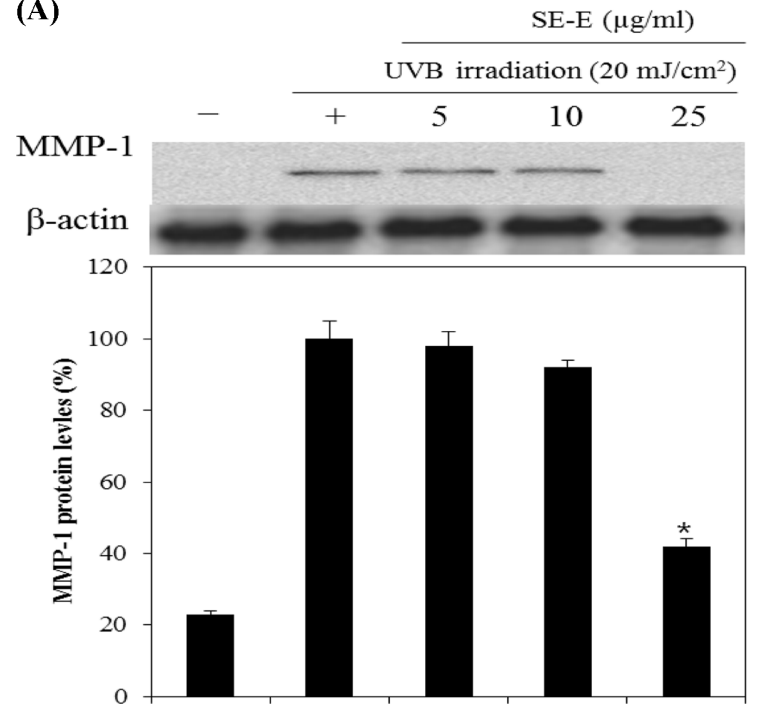

(B)

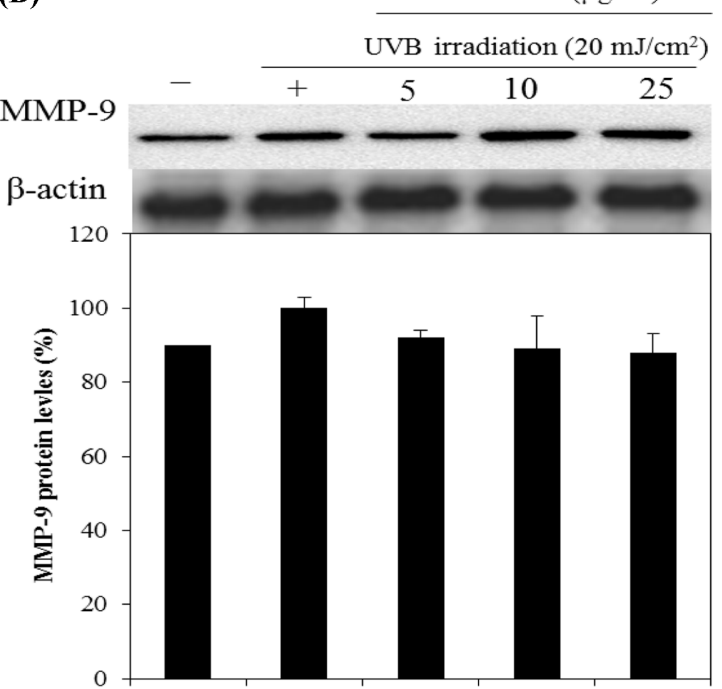

Fig. 4 Effects of SE-E on MMP-1 and MMP-9 expression in CCD-986sk cell. UVB (20 mJ/ $\left./ \mathrm{cm}^{2}\right)$-exposed CCD-986sk cells were cultured for $48 \mathrm{~h}$ in the presence of $S$. polyrhiza. nor, normal control group (non irradiated-vehicle); con, negative control group (UVB irradiated vehicle); SE-E, Ethyl acetate fraction of SE. The results were expressed as the average of triplicate. Significant differences were compared with control at ${ }^{*} p<0.05$ compared with no treatment
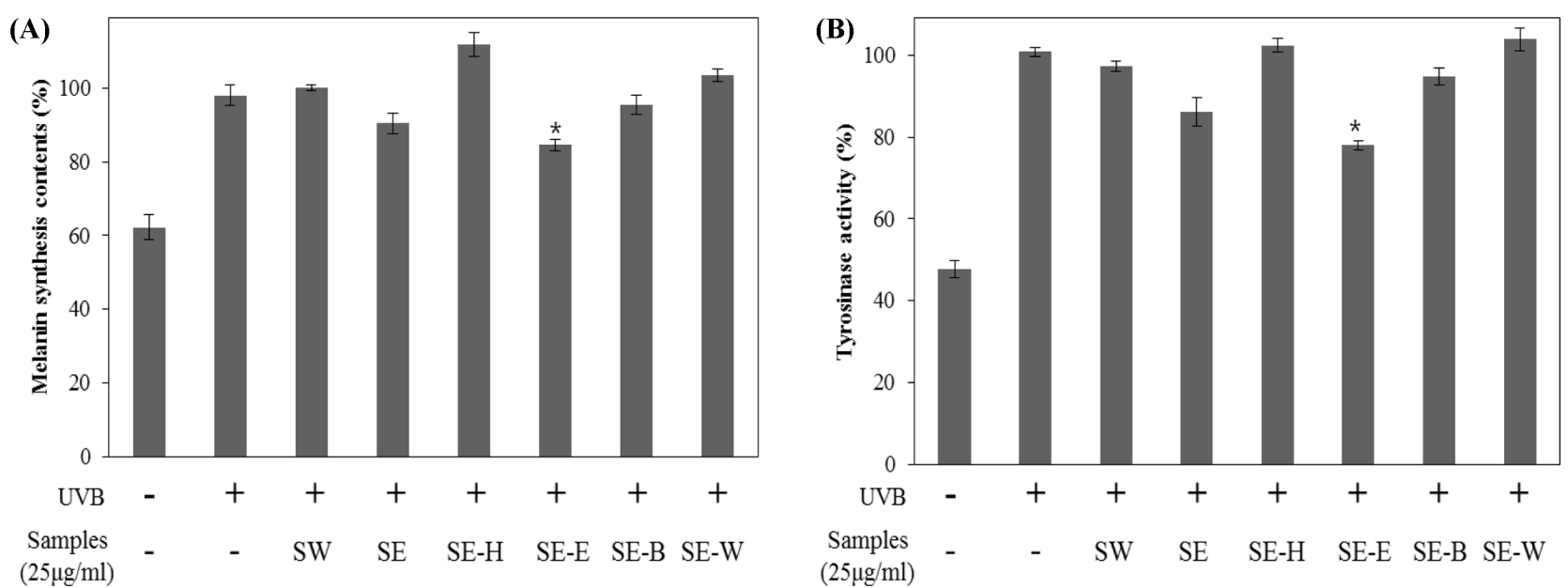

Fig. 5 Inhibition of melanin synthesis and cellular tyrosinase activity of extracts and fractions from S. polyrhiza on melanoma cell(B16F10). $\alpha-M S H$ $(100 \mathrm{nM})$ stimulated cells were cultured for $48 \mathrm{~h}$ in the presence of $S$. polyrhiza. (A), Inhibition of melanin synthesis activity; (B), Inhibition of cellular tyrosinase activity. nor, normal control group (non treated-vehicle); con, negative control group ( $\alpha$-MSH stimulated vehicle); SW, S. polyrhiza extracted with Water; SE, S. polyrhiza extracted with 70\% EtOH; SE-H, Hexane fraction of SE; SE-E, Ethyl acetate fraction of SE; SE-B, Butanol fraction of SE; SE-W, Water fraction of SE. The results were expressed as the average of triplicate. Significant differences were compared with control at $* p<0.05$ compared with no treatment

TRP-1, TRP-2의 promotor에 결합하여 각 각의 유전자 발현을 증가시켜 melanogenesis를 유도하는 것으로 알려져 있다[7]. 이 중 TRP-1과 TRP-2는 tyrosinase related protein 으로 알려져 있는 단백질로서 5,6-dihydroxyindole-2-carboxylic acid (DHICA) 를 흑갈색을 나타내는 indole-5,6-quinone-2- carboxylic acid로 산화하는 효소이며 TRP-2는 DCT라고도 하며 DOPA chrome을 $\mathrm{DHICA}$ 로 이성화 하는 효소이다[38]. MITF의 억제는 tyrosinase 및 TRP-1, TRP-2의 발현억제를 통하여 melanin 색소 생성을 억제할 수 있다. SE-E가 melanin 합성관련 MITF, tyrosinase, TRP-1, TRP-2 protein 발현에 미치는 영향을 $5,10,25 \mu \mathrm{g} / \mathrm{mL}$
농도에서 측정하여 Fig. 6에 나타내었다. 특히, MITF의 경우 SE-E $25 \mu \mathrm{g} / \mathrm{mL}$ 의 농도에서 대조군에 비해 $18.0 \%$ 저해하는 것 을 확인 할 수 있었다. 또한 $25 \mu \mathrm{g} / \mathrm{mL}$ 의 농도에서 tyrosinase 및 TRP-1, TRP-2의 발현이 각각 $21.6,6.3,10.4 \%$ 감소되었다. 이러한 결과는 SE-E가 MITF 억제를 통해 tyrosinase, TRP-1 및 TRP-2의 발현을 저해하고 그 결과 melanin 색소 형성이 억 제되는 미백소재로의 개발 가능성이 있음을 나타낸다.

열악한 환경에서 서식하는 수생식물인 부평초는 민간에서 한 약재 등으로 사용되었음에도 불구하고 그 동안 충분한 연구가 이루어지지 않았다. 본 연구에서는 부평초 추출물 및 부평초 분 

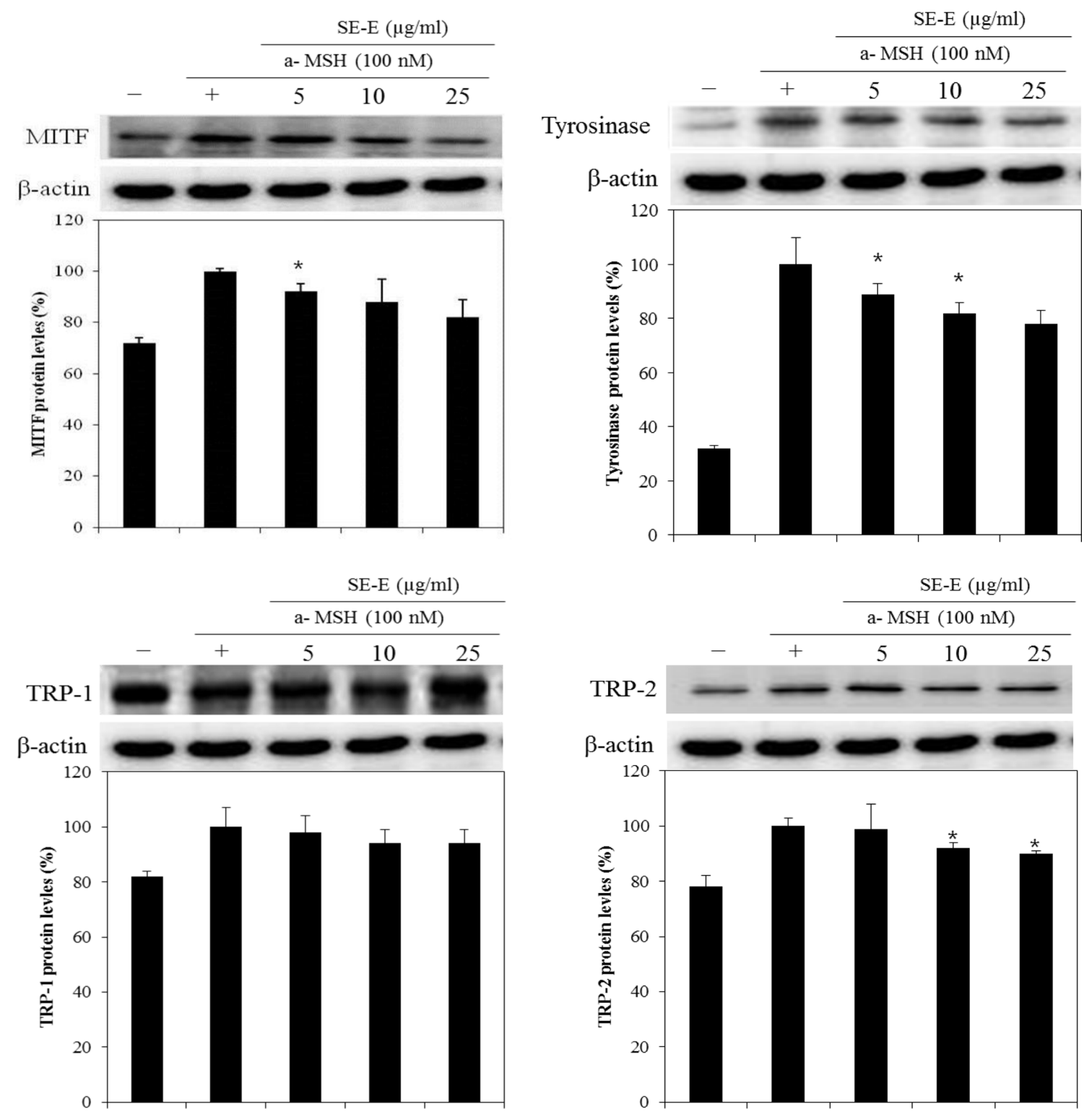

Fig. 6 Effects of SE-E on MITF, Tyrosinase, TRP-1 and TRP-2 expression in melanoma cell (B16F10). $\alpha-M S H$ (100 nM) stimulated cells were cultured for $48 \mathrm{~h}$ in the presence of $S$. polyrhiza. nor, normal control group (non treated-vehicle); con, negative control group ( $\alpha$-MSH stimulated vehicle); SE-E, Ethyl acetate fraction of SE. The results were expressed as the average of triplicate. Significant differences were compared with control at $* p<0.05$ compared with no treatment

획물의 기능성 화장품 소재로서의 효능을 측정하기 위하여 항 산화, 항주름 및 미백 활성을 평가하였으며 그 결과 부평초 $70 \%$ 에탄올 추출물 $(\mathrm{SE})$ 과 이의 에틸아세테이트 분획물 $(\mathrm{SE}-\mathrm{E})$ 이 $\mathrm{DPPH}$ 및 $\mathrm{ABTS}^{+}$라디칼 소거 활성, 세포내 procollagen 생합 성 활성, MMP-1 저해 활성, melanin 생합성 저해 활성, 세포 내 tyrosinase 저해 활성 등에서 우수한 생리활성이 있음을 검 증하였다. 특히 SE-E에서 높은 항주름 및 미백 활성이 확인되 어 우수한 기능성 소재로서 개발 가능성이 높아 졌으며 추가적 인 항균, 항염, 항암 등의 연구가 진행된다면 제약, 화장품, 기 능성 식품 등의 분야에 효과적인 기능성 소재로 활용될 수 있 을 것으로 사료된다.

\section{초 록}

부평초 추출물 및 부평초 분획물의 기능성 화장품 소재로서의 효능을 측정하기 위하여 항산화, 항주름 및 미백 활성을 평가 하였다. $\mathrm{DPPH}$ 와 $\mathrm{ABTS}^{+}$라디칼 소거 활성은 부평초 $70 \%$ 에 탄올추출물의 에틸아세테이트 분획물(SE-E) $100 \mu \mathrm{g} / \mathrm{mL}$ 농도에 서 각각 44.2 와 $74.3 \%$ 로 나타났다. 항주름 활성을 측정하기 위 하여 세포내에서의 procollagen 생합성 활성과 MMP-1 저해 활 성을 측정하였다. 그 결과 부평초 $70 \%$ 에탄올추출물 $(\mathrm{SE})$ 은 25 $\mu \mathrm{g} / \mathrm{mL}$ 농도에서 $48.5 \%$, 같은 농도에서 $\mathrm{SE}-\mathrm{E}$ 는 가장 높은 $57.8 \%$ 의 생합성 활성을 나타내었다. SE와 SE-E의 MMP-1 저 
해활성은 $25 \mu \mathrm{g} / \mathrm{mL}$ 농도에서 각각 13.4 와 $28.5 \%$ 로 나타났다. 마지막으로 미백 효과를 검증하기 위해 melanin 생합성 저해 활성과 세포내 tyrosinase 저해 활성을 측정한 결과, $25 \mu \mathrm{g} / \mathrm{mL}$ 농도에서 $\mathrm{SE}$ 는 각각 9.6 과 $13.8 \%$ 의 저해활성을 나타내었으며 $\mathrm{SE}-\mathrm{E}$ 는 각각 15.4 와 $22.0 \%$ 의 값을 나타내었다. 본 연구의 결과 로부터 SE와 SE-E의 높은 항주름 및 미백 활성이 확인되어 우 수한 기능성 소재로 개발 가능성이 높아 졌으며 추가적인 항균, 항염, 항암 등의 연구가 진행된다면 제약, 화장품, 기능성 식품 등의 분야에 효과적인 소재로 활용될 수 있을 것으로 사료된다.

Keywords 기능성 화장품 - 미백 · 부평초 · 항산화 · 항주름

\section{References}

1. Żukiewicz-Sobczak WA, Adamczuk P, Wróblewska P, Zwoliński J, Chmielewska-Badora J, Krasowska E, Galińska EM, Cholewa G, Piątek J, Koźlik J (2013) Allergy to Selected Cosmetic Ingredients. Postep Derm Alergol 30: 307-310

2. Amasa W, Santiago D, Mekonen S, Ambelu A (2012) Are Cosmetics Used in Developing Countries Safe?. J Toxicology 2012: 8-15

3. Juliano C, Magrini GA (2018) Cosmetic Functional Ingredients from Botanical Sources for Anti-Pollution Skincare Products. Cosmetics 5: 19

4. Kanlayavattanakula M, Louritha N, Chaikula P (2016) Jasmine Rice Panicle: A Safe and Efficient Natural Ingredient for Skin Aging Treatments. J Ethnopharmacology 193: 607-616

5. Svobodova A, Walterova D, Vostalova J (2006) Ultraviolet Light Induced Alteration to the Skin. Biomed Pap Med Fac Univ Palacky Olomouc Czech Repub 150: 25-38

6. Roy A, Sahu RK, Matlam M, Deshmukh VK, Dwivedi J, Jha AK (2013) In vitro Techniques to Assess the Proficiency of Skin Care Cosmetic Formulations. Pharmacognosy Reviews 7: 97-106

7. Lin JW, Chiang HM, Lin YC, Wen KC (2008) Natural Products with Skin-whitening Effects. J Food and Drug Analysis 16: 1-10

8. Smit N, Vicanova J, Pavel S (2009) The Hunt for Natural Skin Whitening Agents. Int J Mol Sci 10: 5326

9. Gilchrest BA (1989) Skin aging and photoaging: an overview. J Am Acad Dermatol 2: 610-613

10. Kang KS, Kim ID, Kwon RH, Heo YY, Oh SH, Kim MA, Jung HJ, Kang HY, Ha BJ (2007) The evaluation of anti-wrinkle effects in oriental herb extract. J Life Sci 17: 1147-1151

11. Lee BG, Kim JH, Ham SG, Lee CE (2014) Study on biological activities of extracts for cosmeceutical development from Lagerstroemia indica L. branch. Korean J Plant Res 27: 29-34

12. Kim DS, Kim DH, Oh MJ, Lee KG, Kook MC, Park CS (2010) Antiaging and whitening activities of ethanol extract of Yuza (Citrus junos SIEB ex TANAKA) by-product. J Soc Cosmet Scientists Korea 36: 137-143

13. Suh SS, Shin JS (1969) Studies on phytosterols. Yakhakhoe Chi 13: 144-146

14. Chi HJ (1981) Irridoid-containing Korean Medicinal plants (I). Kor J Pharmacogn 12(1): 19-22

15. Harborne JB (1986) The natural distribution in angiosperms of anthocyanins acylated with aliphatic dicarboxylic acids. Phytochemistry 25: $1887-1894$

16. Xue Q, Wen-ni H, Cheng X, Jian H, Li-jun W, De-an G, Min Y (2011) Qualitative and quantitative analysis of flavonoids in Spirodela polyrhiza by high-performance liquid chromatography coupled with mass spectrometry. Phytochem Anal 22: 475-483

17. Kim JP, Lee IS, Seo JJ, Jung MY, Kim YH, Y NH, Bae KH (2010) Vitexin, orientin and other flavonoids from Spirodela polyrhiza inhibit adipogenesis in 3T3-L1 cells. Phytother Res 24: 1543-1548
18. Cho SE, Kim BW, Kwon KR, Rhim TJ, Kim DH (2008) The effect of Spirodelae herba pharmacopuncture on adipocyte metabolism, Kor Pharmacopuncture Institute 11(1): 71-82

19. Lee HJ, Kim MH, Choi YY, Kim EH, Hong JK, Kim KS, Yang WM (2016) Improvement of atopic dermatitis with topical application of Spirodela polyrhiza, J Ethnopharmacology 180: 12-17

20. Ahn YS, Seong NS, Ham IH, Cho HY (2004) Study on the effect of medicinal herbs used as Bu-pyung ( $S$. polyrhiza and L. paucicostata) on immune and anti-cancer. Kor J Herbology 19: 117-127

21. Blois MS (1958) Antioxidant activity determination by the use of a stable free radical. Nature 181: 1199-1200

22. Re R, Pellegrini N, Proteggente A, Pannala A, Yang M, Rice-Evans C (1999) Antioxidnt activity applying and improved ABTS radical cation decolorization assay. Free Radic Biol Med 26: 1231-1237

23. Park JG, Kramer BS, Steinberg SM, Carmichael J, Collins JM, Minna JD, Gazdar AF (1987) Chemosensitivity testing of human colorectal carcinoma cell lines using a tetrazolium-based colorimetric assay. Cancer Res 22: 5875-5879

24. Hosoi J, Abe E, Suda T, Kuroki T (1985) Regulation of melanin synthesis of B16 mouse melanoma cells by 1 alpha, 25-dihydroxyvitamin D3 and retinoic acid. Cancer Res 45: 1474-1478

25. Choi SY, Cho HS, Sung NJ (2006) The antioxidative and nitrite scavenging ability of solvent extracts from wild grape (Vitis Coignetiea) skin. J Korean Soc Food Sci Nutr 35: 961-966

26. Min KJ, Song JW, Cha CG (2008) The antioxidative and antitumor activity of extracts of Agrimonia pilosa. J Fd Hyg Safety 23: 149-156

27. Kim MS, Kim KH, Jo JE, Choi JJ, Kim YJ, Kim JH, Jang SA, Yook HS (2011) Antioxidative and antimicrobial activities of Aruncus dioicus var. kamtschaticus Hara extracts. J Korean Soc Food Sci Nutr 40: 47-55

28. Parfitt AM, Simon LS, Villanueva AR, Krane SM (1987) Procollagen type I carboxy-terminal extension peptide in serum as a marker of collagen biosynthesis in bone. correlation with iliac bone formation rates and comparison with total alkaline phosphatase. J Bone Miner Res 2: 427-436

29. Koo BS, Hwang EI, So SH, Lee SK, Han GH, Kim NM (2007) Effect of Torilis Fructus on Procollagen Biosynthesis and Activity of Matrix Metalloproteinase-I (MMP-1) in Human Dermal Fibroblast. Kor J Pharmacogn 38(4): 349-353

30. Fisher GJ, Voorhees JJ (1999) Molecular mechanism of photoaging in human skin in vivo and their prevention by all-trans retinoic acid. Photochem Photobiol, 69: 154-158

31. Fanger GR, Johnson NL, Johnson GL (1997) MEK kinases are regulated by EGF and selectively interact with Rac/Cdc42. EMBO J 16: 4961-4972

32. Park SH, Lee KH, Han CS, Kim KH, Kim YH (2010) Inhibitory Effects of Carex humilis Extract on Elastase Activity and Matrix Metalloproteinase1 Expression. J Soc Cosmet Scientists Korea 36: 129-136

33. Lin CB, Babiarz L, Liebel F, Roydon Price E, Kizoulis M, Gendi menico GJ, Fisher DE, Seiberg M (2002) Modulation of microphthal miaassociated transcription factor gene expression alters skin pigmentation. $\mathrm{J}$ Invest Dermatol 119: 1330-1340

34. Ando S, Ando O, Suemoto Y, Mishima Y (1993) Tyrosinase gene transcription and its control by melanogenic inhibitors. J Invest Dermatol 100(2 Suppl): 150S-155S

35. Cho YH (2008) Inhibitory Effect of Enteromorpha linza on the Melanogenesis in B16 Melanoma Cells. Kor J Pharmacogn 39: 174-178

36. Jeon MJ, Kim MH, Jang HJ, Lee SW, Kim JH, Kim HS, Lee SH (2012) Whitening effect of Hizikia fusiformis ethanol extract and its fractions. J Life Sci 22: 889-896

37. Abdel-Malek ZA, Swope VB, Suzuki I, Harriger D, Boyce ST, Urabe K, Hearing VJ (1995) Mitogenic and melanogenic stimulation of normal human melanocytes by melanotropic peptides. Proc Natl Acad Sci USA 92: $1789-1793$

38. Jimenez CC (2004) Inhibition of melanogenesis in response to oxidative stress: transient down regulation of melanocyte differentiation markers and possible involvement of microphthalmia transcription factor. J. Cell Sci 114: 2335-2344 